\title{
KRISIS COVID-19: PERSPEKTIF HUKUM INTERNASIONAL TERHADAP PANDEMI
}

\section{(Covid-19 Crisis: An International Law Perspective to Pandemics)}

\author{
Sabrina Nadilla \\ Pusat Penelitian dan Pengembangan Hak Asasi Manusia \\ Badan Penelitian dan Pengembangan Hukum dan Hak Asasi Manusia \\ Jalan H.R Rasuna Said Kav. 4-5, Kuningan, Jakarta Selatan 12940 \\ e-mail: sabrina.nadilla@kemenkumham.go.id
}

\begin{abstract}
Abstrak
Kegagapan negara-negara dunia dalam penanganan Pandemi Covid-19 menimbulkan pertanyaan mengenai eksistensi kerangka kerja yang digunakan untuk menyelesaikan krisis kesehatan global. Lebih jauh, artikel ini mengungkapkan bahwa hukum internasional memiliki mekanisme khusus dalam penanganan pandemi melalui operasionalisasi International Health Regulation (IHR) yang dikoordinasikan secara global oleh organisasi internasional WHO. Melalui perspektif hukum internasional, artikel ini bermaksud mengelaborasi kerangka kerja hukum internasional yang memuat kewajiban, kewenangan, prosedur, serta peran dan tantangan yang dihadapi pada penanganan pandemi global, termasuk dalam krisis Covid-19 yang masih bergulir hingga saat ini. Artikel ini menemukan fakta bahwa, IHR 2005 sebagai kerangka kerja hukum internasional, tidak bisa dianggap sebagai instrumen 'one size fits all' yang dapat menyelesaikan seluruh permasalahan penanganan krisis kesehatan global.
\end{abstract}

Kata kunci: hukum internasional, pandemi, WHO, International Health Regulation

\section{Abstract}

The drawbacks faced by countries while handling the Covid-19 crisis raises questions about the existence of a framework to resolve the global health crisis. Furthermore, this article identifies a particular mechanism in handling pandemics through the operationalization of the International Health Regulation (IHR) that is coordinated globally by the World Health Organization. Through the perspective of international law, this article aims to elaborate the framework of international law that depicts the obligations, authorities, procedures, roles, as well as faced challenges in handling global pandemics, including the Covid-19 crisis that is still taking place today. This article finds the fact that, the IHR 2005 as an international legal framework, cannot be considered as a 'one size fits all' instrument that can solve all problems in resolving global health crisis.

Keywords: international law, pandemics, WHO, International Health Regulation

\section{A. Pendahuluan}

Memasuki dekade baru, perhatian dunia tertuju pada Wuhan, ibukota provinsi Hubei, Republik Rakyat Tiongkok. Sejak akhir 2019, Wuhan melaporkan adanya serangkaian kematian yang disebabkan oleh penyakit dengan karakteristik mirip pneumonia (pneumonia- like illness). ${ }^{1}$ Dengan penyebaran lokal yang semakin meluas, otoritas kesehatan Wuhan melaporkan kasus ini pada Komisi Kesehatan Nasional Tiongkok, Chinese Center for Disease Control and Prevention (CDC Tiongkok), hingga memberikan notifikasi pada organisasi kesehatan dunia (WHO). ${ }^{2}$ Pada Januari 2020,

1 Zunyou Wu and Jennifer M. McGoogan, "Characteristics of and Important Lessons From the Coronavirus Disease 2019 (COVID-19) Outbreak in China" (JAMA Network, 2020), 1240.

2 Ibid. 
CDC Tiongkok berhasil mengidentifikasi SARSCoV-2, jenis coronavirus terbaru penyebab lima belas dari lima puluh sembilan kasus pneumonia Wuhan. Jenis coronavirus ini pula yang kemudian diidentifikasi sebagai penyebab Covid-19. ${ }^{3}$ Kondisi demikian mengharuskan Tiongkok untuk melakukan tindakan mitigasi. Dalam jangka waktu kurang dari satu bulan sejak identifikasi SARS-CoV-2, pemerintah Tiongkok memberlakukan karantina total (lockdown) di Kota Wuhan dan lima belas kota lainnya, hingga meniadakan liburan perayaan Tahun Baru Imlek. ${ }^{4}$ Upaya pencegahan tersebut, bagaimanapun, tidak cukup kuat menahan laju penyebaran Covid-19 keluar dari negeri. Terhitung sejak akhir Januari, kasus-kasus baru bermunculan di luar Tiongkok seperti: Thailand, Jepang, dan Korea Selatan di wilayah Asia, serta Perancis dan Jerman di wilayah Eropa, masingmasing memiliki kluster penyebaran yang, ketika ditelusuri, memiliki riwayat bepergian dari dan menuju Tiongkok. ${ }^{5}$

Seiring dengan peningkatan status krisis kesehatan menjadi kondisi darurat kesehatan berskala internasional/public health emergency of international concern (PHEIC), episentrum penyebaran Covid-19 telah bergeser ke Lombardy, Italia yang membentuk kluster baru di wilayah Eropa. Per Maret 2020, angka penularan di wilayah Eropa telah mencapai 4.505 kasus dan 113 kematian. ${ }^{6}$ Dalam hal ini, keterlambatan deteksi dini terhadap kluster penyebaran semakin mempersulit proses isolasi kasus-kasus lokal yang tersebar di seluruh wilayah Eropa. ${ }^{7}$ Eskalasi pada kasus penyebaran dan persentase tingkat kematian akibat Covid-19 -total hingga 110.000 kasus tersebar di 110 negara dengan tingkat kematian mencapai 3,9 persen secara global, ${ }^{8}$ akhirnya mendorong WHO untuk mendeklarasikan kondisi tersebut sebagai Pandemik pada akhir Maret lalu. ${ }^{9}$ Status pandemik global ini, 'memaksa' negara-negara di dunia untuk mengambil langkah drastis dalam rangka menekan laju penyebaran Covid-19.

Dari perspektif hukum internasional, WHO merupakan pemegang mandat utama dalam urusan kesehatan publik skala global. Sebagaimana penanganan pandemi terdahulu, WHO kembali mengoperasionalkan kerangka kerja International Health Regulation (IHR) 2005 dalam penanganan pandemi Covid-19. Bagaimanapun, kegagapan negara-negara dunia bahkan negara maju sekalipun menimbulkan pertanyaan mengenai mekanisme dari kerangka kerja yang digunakan untuk menyelesaikan krisis kesehatan global. Berdasarkan narasi di atas, rumusan masalah dari artikel ini ialah bagaimana mekanisme penanganan pandemi Covid-19

European Centre for Disease Prevention and Control, "Event Background COVID-19," COVID-19.

4 Wu and McGoogan, "Characteristics of and Important Lessons From the Coronavirus Disease 2019 (COVID-19) Outbreak in China," 1240.

5 World Health Organization, Novel Coronavirus (2019-NCoV) Situation Report - 1, 20 January 2020 (Geneva, 2020), https://www.who.int/docs/default-source/coronaviruse/situation-reports/20200121-sitrep-1-2019-ncov.pdf? sfvrsn=20a99c10_4; European Centre for Disease Prevention and Control, "Event Background COVID-19."

6 Gianfranco Spiteri et al., "First Cases of Coronavirus Disease 2019 (COVID-19) in the WHO European Region, 24 January to 21 February 2020," Eurosurveillance 25, no. 9 (2020): 4.

Ibid., 1.

8 World Health Organization, "WHO Director-General's Opening Remarks at the Media Briefing on COVID-19 - 3 March 2020," last modified 2020, accessed May 2, 2020, https://www.who.int/dg/speeches/detail/who-director-general-sopening-remarks-at-the-media-briefing-on-covid-19---3-march-2020.

9 Jamie Ducharme, "World Health Organization Declares COVID-19 a 'Pandemic.' Here's What That Means," TIME, last modified 2020, accessed May 2, 2020, https://time.com/5791661/who-coronavirus-pandemic-declaration/. 
dalam kerangka kerja hukum internasional?

Untuk dapat menjawab rumusan masalah, pembahasan dalam artikel ini akan dibagi ke dalam tiga bagian: bagian pertama akan mendeskripsikan penanganan situasi pandemi dalam kerangka kerja hukum internasional dengan perhatian khusus pada organisasi internasional WHO. Pada bagian kedua, artikel ini berupaya untuk mengelaborasi kewajiban, kewenangan, prosedur, serta peran dan tantangan yang dihadapi pada penanganan pandemi terdahulu. Terakhir, bagian ketiga pembahasan artikel ini akan mengulas perkembangan penanganan pandemi Covid-19 melalui kerangka kerja International Health Regulation 2005.

\section{B. Metode Penelitian}

Pada prinsipnya, studi ini merupakan studi hukum doktrinal, sebuah studi hukum yang berfokus pada "prinsip hukum yang dihasilkan oleh pengadilan dan legislator; kaidah hukum yang berdiri sendiri dengan argumen dan persepsi yang berdasar pada premis normatif dalam bentuk teks hukum dan statuta." ${ }^{10}$ Lebih lanjut, studi hukum doktrinal merupakan sebuah proses yang terdiri dari dua bagian, yakni pertama, mengidentifikasi sumber hukum dan kedua, menginterpretasikan dan menganalisis teks hukum tersebut. ${ }^{11}$ Dalam hal ini, sumber hukum yang relevan dengan kerangka kerja penanganan krisis kesehatan ialah Konstitusi World Health Organization dan International Health Regulation (IHR)
2005. Untuk melengkapi interpretasi dan analisis dokumen hukum tersebut, analisis juga dilakukan terhadap data sekunder lain terkait dengan (i) organisasi kesehatan internasional WHO; (ii) kerangka kerja penanganan pandemi dalam hukum internasional; (iii) pandemi dalam perspektif kesehatan gloval; serta (iv) informasi faktual seputar penyebaran Covid-19 dalam jangka waktu November 2019 hingga Mei 2020.

\section{Pembahasan}

\section{World's Health Organization dan Penanganan Pandemi dalam Kerangka Hukum Internasional}

Sejarah penanganan krisis kesehatan internasional dapat ditelusuri hingga akhir abad 19. Pada 1851, negara-negara Eropa berkumpul di Paris untuk membentuk sebuah kerangka kerja umum dalam rangka mengharmonisasikan respons terhadap penyebaran penyakit antar lintas batas negara. ${ }^{12}$ Cara yang umum digunakan dalam era ini ialah melalui tindakan karantina terhadap turis dan transportasi laut yang datang. Memasuki abad 20, lahir dua organisasi internasional kesehatan yakni Pan-American Health Organization (PAHO) pada 1902 dan Office Internationale d'Hygiène Publique pada 1907. Kedua organisasi ini merupakan cikal bakal dari WHO dengan adanya pergeseran ke dalam sebuah struktur institusi. ${ }^{13}$ Penekanan pada unsur regional dalam hal ini menjadi penting, mengingat kerja sama kesehatan menyaratkan adanya aksi baik di tingkat global maupun lokal. ${ }^{14}$ Pasca Perang Dunia II, berkembangnya

10 Reza Banakar, Normativity in Legal Sociology: Methodological Reflections on Law and Regulation in Late Modernity (London: Springer, 2015), 29; Muhammad Helmy Hakim, "Pergeseran Orientasi Penelitian Hukum: Dari Doktrinal Ke Sosio Legal," SYARIAH Jurnal Hukum dan Pemikiran 16, no. 2 (2016): 106; Robert Cryer et al., Research Methodologies in EU and International Law (Portland: Hart Publishing, 2011), 38.

11 Amrit Kharel, "Doctrinal Legal Research," SSRN Electronic Journal 16 (2018): 9.

12 Armin Von Bogdandy and Pedro A Villarreal, International Law on Pandemic Response: A First Stocktacking in Light of the Coronavirus Crisis, MPIL Research Paper Series (Heidelberg, 2020), 3.

13 David W. Kennedy, "The Move to Institutions," Cardozo Law Review 8 (1987): 841-842.

14 L. Lerer and R. Matzopoulos, "'The Worst of Both Worlds': The Management Reform of the World Health Organization," 
institusi multilateral mendorong kelahiran WHO sebagai badan khusus dalam urusan kesehatan internasional. Secara yuridis, WHO resmi berdiri sejak Konstitusi WHO mulai berlaku (entered into force) pada 7 April 1948. ${ }^{15}$ Selanjutnya, First World Health Assembly Jenewa 1948 memberikan mandat prioritas bagi WHO, yakni malaria, tuberkulosis, penyakit kelamin, kesehatan ibu dan anak, teknik sanitasi, serta nutrisi. Lebih lanjut, WHO juga terlibat dalam pencegahan penyakit skala luas serta upaya kontrol termasuk kampanye masal melawan frambusia, endemik sifilis, kusta, dan trakoma. ${ }^{16}$

Konstitusi WHO menyediakan prosedur pengambilan keputusan utama di dalam organisasi, yang memiliki kewenangan cukup luas apabila dibandingkan dengan organisasi internasional lainnya. Sebagaimana tercantum dalam Pasal 21 dan 22, disebutkan:

\section{Article 21}

The Health Assembly shall have authority to adopt regulations concerning:

(a) sanitary and quarantine requirements and other procedures designed to prevent the international spread of disease;

(b) nomenclatures with respect to diseases, causes of death and public health practices;

(c) standards with respect to diagnostic procedures for international use;

(d) standards with respect to the safety, purity and potency of biological, pharmaceutical and similar products moving in international commerce;

(e) advertising and labelling of biological, pharmaceutical and similar products moving in international commerce.

Article 22

Regulations adopted pursuant to Article 21 shall come into force for all Members after due notice has been given of their adoption by the Health Assembly except for such Members as may notify the Director-General of rejection or reservations within the period stated in the notice.

Kedua Pasal ini menetapkan kewenangan WHO untuk mengeluarkan peraturan yang mengikat bagi para negara anggota tanpa melalui prosedur ratifikasi terlebih dahulu. Hal ini, tentu merupakan karakteristik yang tidak umum dalam lanskap organisasi internasional pada umumnya. Lebih jauh, konstitusi WHO mengatur bahwa kewenangan pembentukan norma berada pada World Health Assembly, yang mampu membentuk peraturan setelah memenuhi suara mayoritas dua per tiga dari negara anggota yang hadir dan memberikan suaranya. ${ }^{17}$ Pembentukan norma hukum di WHO dengan demikian, merupakan proses yang dilakukan oleh para ahli, diplomat, dan teknokrat.

\section{a. International Health Regulation sebagai "Hukum Pandemi Internasional"}

Tiga instrumen hukum utama yang diadopsi melalui mekanisme Pasal 21 Konstitusi WHO yakni International Sanitary Regulations (ISR), International Health Regulations (IHR), dan Nomenclature Regulations. ${ }^{18}$ Pada 1951, ISR

International Journal of Health Services 31, no. 2 (2001): 425.

15 United Nations, "Constitution of the World Health Organization," United Nations Treaty Collection, accessed May 3, 2020, https://treaties.un.org/Pages/ShowMTDSGDetails.aspx?src=UNTSONLINE\&tabid=2\&mtdsg_no=IX$1 \&$ chapter=9\&lang=en.

16 Michael Mccarthy, "A Brief History of the World Health Organization D," The Lancet 360 (2002): 1111.

17 Pasal 19 Konstitusi WHO

18 Bogdandy and Villarreal, International Law on Pandemic Response: A First Stocktacking in Light of the Coronavirus Crisis, 5. 
lahir sebagai predesesor dalam penanganan penyebaran penyakit menular setelah proses pengambilan keputusan World Health Assembly keempat. ${ }^{19}$ Dasar dari kerangka kerja ISR ialah persyaratan bagi pemerintah negara pihak untuk melaporkan penyebaran penyakit menular tertentu; informasi tersebut kemudian dapat disebarkan ke negara anggota lainnya untuk menjadi dasar pengambilan tindakan-tindakan yang diperlukan. ${ }^{20}$ Selanjutnya pada 1969, ISR mengalami serangkaian revisi dan berubah nomenklatur menjadi International Health Regulations. ${ }^{21}$ Perubahan ISR menjadi IHR dimaksudkan untuk "memperkuat penggunaan prinsip-prinsip epidemiologi yang diterapkan dalam skala internasional, untuk mendeteksi, mengurangi, atau mengeliminasi sumber penyebaran infeksi; untuk meningkatkan sanitasi di dalam dan sekitar pelabuhan dan bandar udara; untuk mencegah diseminasi vektor; dan, secara umum, mendorong aktivitas epidemiologis pada level nasional sehingga tidak terdapat risiko infeksi luar."22 IHR dalam hal ini hadir sebagai regulasi yang secara spesifik mengatur sebagian kecil jenis penyakit; dengan mendorong adanya aktivitas epidemiologi, satu-satunya kewajiban bagi negara pihak ialah terkait kapasitas melaporkan penyakit tertentu dan menjaga kapabilitas kesehatan minimum pada pelabuhan dan batas-batas negara. ${ }^{23}$

Meskipun kewajiban negara pihak terbilang mudah dan secara langsung mengikat para negara anggota, pada praktiknya, kepatuhan terhadap IHR berangsur-angsur menurun. ${ }^{24} \mathrm{Hal}$ ini dilatarbelakangi oleh kekhawatiran negaranegara pihak akan embargo, turunnya reputasi negara, hingga stigma negatif dan diskriminasi sebagai buntut praktik pelaporan tersebut. ${ }^{25}$ Kondisi ini kemudian menimbulkan polemik dalam upaya mengontrol laju penyebaran penyakit menular: rendahnya angka pelaporan penyebaran penyakit menjadi praktik umum dan WHO tidak memiliki sarana penegakan hukum. Dalam hal ini, IHR hanya mampu bertindak atas dasar informasi dari laporan formal negara pihak, "[IHR] therefore clearly hampered by reliance on governments fulfilling their obligations in the face of significant disincentives to comply." ${ }^{26}$ Relevansi dan efektivitas sistem pengintaian yang berusaha dibangun melalui kerangka kerja IHR, dengan demikian, semakin memudar seiring berjalannya waktu.

Kasus penyebaran Severe Acute Respiratory Syndrome (SARS) pada 2003 lagi-lagi menjadi penanda akan pentingnya global governance dalam penanganan penyakit menular. Pengalaman menghadapi minimnya informasi mengenai perkembangan penyakit dan mengoordinasikan respons skala global dalam menahan laju penyebaran penyakit memaksa publik internasional untuk membentuk instrumen yang mampu mengatur kedaruratan

19 World Health Organization, International Health Regulation, 2nd ed. (Geneva: WHO, 2005), 1.

20 Sara E. Davies, Adam Kamradt-Scott, and Simon Rushton, Disease Diplomacy: International Norms and Global Health Security (Baltimore: Johns Hopkins University Press, 2015), 5.

21 WHO Official Records, No. 176, 1969, resolution WHA22.46 and Annex I.

22 World Health Organization (1969), International Health Regulation, 3rd ed. (Geneva: WHO, 1983).

23 Rebecca Katz and Julie Fischer, "The Revised International Health Regulations : A Framework for Global Pandemic Response," Global Health Governance 3, no. 2 (2010): 2.

24 Davies, Kamradt-Scott, and Rushton, Disease Diplomacy: International Norms and Global Health Security, 5.

25 Bogdandy and Villarreal, International Law on Pandemic Response: A First Stocktacking in Light of the Coronavirus Crisis, 5; Lawrence O Gostin, "Influenza A (H1N1) and Pandemic Preparedness Under the Rule of International Law" (JAMA Network, 2009), 2376.

26 Davies, Kamradt-Scott, and Rushton, Disease Diplomacy: International Norms and Global Health Security, 5. 
kesehatan global di masa mendatang. Setelah mengalami proses yang cukup panjang, World Health Assembly mengadopsi revisi IHR pada 2005 dan resmi mengikat 196 negara pihak pada Juni 2007. ${ }^{27}$ IHR 2005 bertujuan untuk "prevent, protect against, control and provide a public health response to the international spread of disease in ways that are commensurate with and restricted to public health risks, and which avoid unnecessary interference with international traffic and trade." 28 Pembaruan terhadap regulasi ini membawa harapan baru bagi penanganan krisis kesehatan global dengan beberapa ketentuan kunci
Pertama, ruang lingkup IHR 2005 melampaui jenis-jenis penyakit tertentu, hal ini termasuk peristiwa yang dapat memicu terjadinya kedaruratan kesehatan publik dalam skala internasional (public health emergency of international concern/PHEIC). Kedua, IHR menekankan pada pentingnya komunikasi dan kerja sama dalam skala global untuk deteksi dini dan mitigasi terhadap potensi terjadinya PHEIC. Hal tersebut meliputi kebijakan negara pihak untuk mengembangkan cara-cara deteksi, pelaporan, dan merespons kedaruratan kesehatan publik. Kondisi ini menyaratkan negara pihak untuk membentuk focal point

Tabel 1 Perbandingan IHR 1969 dan IHR 2005

\begin{tabular}{|c|c|c|}
\hline Komponen IHR & IHR 1969 & IHR 2005 \\
\hline Ruang Lingkup & $\begin{array}{l}\text { Kolera, Plague, Penyakit Kuning, dan } \\
\text { Cacar; Penanganan pada Perbatasan }\end{array}$ & $\begin{array}{l}\text { Public Health Emergency of International } \\
\text { Concern; Deteksi dan Penahanan pada } \\
\text { Sumber Wabah }\end{array}$ \\
\hline Komunikasi & $\begin{array}{l}\text { Negara mengirimkan laporan ke WHO } \\
\text { melalui faksimile }\end{array}$ & $\begin{array}{l}\text { IHR National Focal Point melakukan } \\
\text { laporan melalui website WHO }\end{array}$ \\
\hline Notifikasi & $\begin{array}{l}\text { Melaporkan ke WHO dalam jangka waktu } \\
24 \text { jam }\end{array}$ & $\begin{array}{l}\text { Melaporkan ke WHO dalam jangka waktu } \\
24 \text { jam dan } 72 \text { jam untuk merespons dan } \\
\text { meminta tindak lanjut }\end{array}$ \\
\hline $\begin{array}{c}\text { Respons } \\
\text { Terkoordinasi }\end{array}$ & $\begin{array}{l}\text { Tidak ada mekanisme koordinasi respons } \\
\text { internasional dalam menahan penyebaran } \\
\text { penyakit }\end{array}$ & $\begin{array}{l}\text { Pendampingan dalam respons dan } \\
\text { rekomendasi tindakan }\end{array}$ \\
\hline $\begin{array}{c}\text { Kewenangan } \\
\text { WHO }\end{array}$ & $\begin{array}{l}\text { WHO tidak berwenang meminta inquiry, } \\
\text { bergantung pada notifikasi resmi dari } \\
\text { negara pihak }\end{array}$ & $\begin{array}{l}\text { WHO dapat meminta permohonan } \\
\text { informasi berdasarkan sumber tidak } \\
\text { resmi dan dimungkinkan untuk meminta } \\
\text { informasi tambahan }\end{array}$ \\
\hline $\begin{array}{l}\text { Kapasitas } \\
\text { Nasional }\end{array}$ & $\begin{array}{l}\text { Menyediakan pemeriksaan dan pengawasan } \\
\text { penyakit dalam pintu masuk negara }\end{array}$ & $\begin{array}{l}\text { Menyediakan pemeriksaan dan pengawasan } \\
\text { penyakit dalam pintu masuk negara; } \\
\text { Memenuhi kapasitas minimal dalam hal } \\
\text { deteksi, pelaporan, dan penilaian }\end{array}$ \\
\hline $\begin{array}{l}\text { Kapabilitas } \\
\text { Respons }\end{array}$ & $\begin{array}{l}\text { Kontrol kesehatan publik yang telah } \\
\text { ditentukan sebelumnya }\end{array}$ & $\begin{array}{l}\text { Fleksibel, respons berbasis bukti yang } \\
\text { beradaptasi terhadap sifat ancaman }\end{array}$ \\
\hline
\end{tabular}

Sumber: Katz dan Fischer (2010); WHO (2005) dengan modifikasi

27 Lawrence O Gostin, Mary C Debartolo, and Eric A Friedman, "The International Health Regulations 10 Years on : The Governing Framework for Global Health Security," The Lancet 386, no. 10009 (2015): 2222, http://dx.doi.org/10.1016/ S0140-6736(15)00948-4.

28 World Health Organization, International Health Regulation, 1. 
nasional IHR yang bertugas menjalin komunikasi dengan WHO, serta memenuhi kapasitas minimum dalam pengintaian dan respons penyakit sebagaimana tercantum dalam Annex I IHR 2005. Melalui mekanisme ini, negara pihak perlu memberikan notifikasi kepada WHO dalam jangka waktu 24 jam setelah adanya penilaian skala nasional terhadap peristiwa yang memicu risiko kesehatan publik bagi negara lain yang memerlukan respons internasional terkoordinasi. Sebaliknya, WHO akan mengoordinasikan komunikasi antar negara, menyediakan pendampingan teknis bagi negara, dan bekerjasama dengan para ahli untuk menyusun rekomendasi mitigasi dari konsekuensi peristiwa tersebut.

\section{b. Public Health Emergency of International Concern, Sebuah Sistem Kewaspadaan Global}

Pergeseran ruang lingkup yang meliputi kondisi kedaruratan kesehatan skala internasional (PHEIC) merupakan salah satu pembaruan krusial yang tercantum dalam IHR 2005. WHO menjadi satu-satunya institusi yang memiliki kewenangan untuk mendeklarasikan dan mencabut status PHEIC, tentunya setelah mempertimbangkan informasi dari negara pihak, Instrumen pengambilan keputusan, saran dari Komite Darurat, prinsip-prinsip dan bukti ilmiah, serta penilaian risiko terhadap kesehatan manusia, penyebaran internasional, dan interferensi terhadap lalu lintas internasional. ${ }^{29}$ Deklarasi status PHEIC meningkatkan kewaspadaan terhadap "peristiwa luar biasa" (extraordinary event) yang, pertama, tidak dapat diselesaikan hanya pada level nasional, dan kedua, berpotensi membawa risiko penyebaran internasional. Lebih jauh, kewenangan mendeklarasikan status PHEIC tak hanya meningkatkan respons internasional terhadap kondisi global, namun juga merepresentasikan perangkat istimewa dalam organisasi internasional, mengingat PHEIC memberikan kewenangan tunggal yang berpotensi memiliki dampak luas. ${ }^{30}$ Penetapan status PHEIC bahkan dapat berlaku bagi kasus penyebaran yang terjadi hanya dalam lingkup satu negara, mengingat penilaian terhadap risiko selalu mengisyaratkan adanya ketidakpastian. ${ }^{31}$

Kewenangan deklarasi PHEIC yang berdampak luas memerlukan adanya safeguard dalam keseluruhan prosedurnya. Dalam hal ini, IHR mengatur keberadaan Komite Darurat (Emergency Committee) yang memberikan pandangan terkait deklarasi, pencabutan, dan rekomendasi seputar status PHEIC. Komite ini terdiri dari para ahli yang dipilih melalui IHR Expert Roster serta panel penasihat ahli lainnya dari organisasi. ${ }^{32}$ Keanggotaan Komite Darurat juga perlu merefleksikan representasi geografis, termasuk representasi dari negara terdampak. Pasca pendeklarasian status PHEIC oleh WHO, hal ini turut disertai dengan adanya rekomendasi sementara (temporary recommendations) yang memuat saran-saran bagi negara mengenai caracara yang spesifik untuk menghadapi keadaan darurat tersebut. ${ }^{33}$ Rekomendasi ini, bersifat kontekstual dengan kasus-kasus yang terjadi, dengan jenis penanganan yang berbeda untuk tiap penyakit, lokasi, dan latar sosio-ekonomi

29 Pasal 12 ayat (4) International Health Regulation (IHR) 2005

30 Bogdandy and Villarreal, International Law on Pandemic Response: A First Stocktacking in Light of the Coronavirus Crisis, 11.

31 Ibid., 12.

32 Pasal 48 International Health Regulation 2005

33 Pasal 15 International Health Regulation 2005 
suatu negara. ${ }^{34}$ Terlepas dari mekanisme yang dibentuk oleh IHR, bagaimanapun, status PHEIC dan rekomendasi sementara masih mengalami kendala dalam pelaksanaannya yang akan dibahas lebih lanjut pada subbagian selanjutnya dari artikel ini.

\section{IHR dan Kesiapan Pandemi: Praktik Penanganan Pandemi Pasca Revisi IHR 2005}

Meskipun kesiapsiagaan dalam penanganan pandemi tidak secara eksplisit tercantum di dalam IHR 2005, faktanya, IHR menjadi rujukan utama bagi negara pihak dalam persiapan menghadapi pandemi. ${ }^{35} \mathrm{Hal}$ ini mengingat, posisi IHR sebagai instrumen hukum internasional terkuat yang mampu mengintegrasikan pemangku kebijakan dalam kerangka kerja deteksi dan respons penyakit dalam skala global. ${ }^{36}$ Dalam konteks pandemic preparedness, IHR menyaratkan negara pihak untuk "establish, operate and maintain a national public health emergency response plan, including the creation of multidisciplinary/multisectoral teams to respond to events that may constitute a public health emergency of international concern." ${ }^{37}$ Dengan kata lain, kesuksesan dari kerangka kerja IHR dalam penanganan pandemi akan sangat bergantung pada kapasitas nasional dan kerja sama dari masing-masing negara pihak.

\section{a. H1N1 2009 dan Ebola 2014, Pandemi Mo- dern yang 'Menguji' Operasional IHR 2005}

Kurang dari dua tahun setelah IHR 2005 resmi berlaku, publik internasional dihadapkan pada pandemi pertama di abad ke 21. Tepatnya pada Maret 2009, virus H1N1 -yang juga dikenal sebagai flu babi (swine influenza)-menyebar dari sebuah desa kecil di Meksiko hingga ke seluruh penjuru dunia hanya dalam hitungan minggu. ${ }^{38}$ Peristiwa luar biasa ini kemudian menjadi momentum pengujian terhadap mekanisme yang disediakan oleh IHR pasca dilakukan revisi. Awal mula terdeteksinya penyebaran virus H1N1 ialah setelah Kementerian Kesehatan Mexico mulai mendeteksi keluhan penyakit sejenis influenza (influenza-like illness) yang tidak biasa. ${ }^{39}$ Pada awal April, otoritas kesehatan Meksiko meningkatkan pengintaian yang berhasil mendeteksi peningkatan penyebaran di desa La Gloria. Pada saat yang sama, sistem pengintaian Pan American Health Organization (PAHO) mengidentifikasi peningkatan perhatian media terkait penyebaran penyakit tersebut dan meminta informasi lebih lanjut dari focal point IHR Mexico. ${ }^{40}$ Sebagai respons, NFP Meksiko menyelesaikan penilaian risiko menggunakan instrumen IHR, melaporkan bahwa peristiwa La Gloria "might constitute a Public Health Emergency of International Concern." 41

Menanggapi situasi demikian, Direktur Jenderal WHO pada saat itu, Dr. Margaret Chan, menyelenggarakan pertemuan dengan Komite Darurat pada akhir April 2009. Berdasarkan

34 Bogdandy and Villarreal, International Law on Pandemic Response: A First Stocktacking in Light of the Coronavirus Crisis, 15.

35 Katz and Fischer, "The Revised International Health Regulations : A Framework for Global Pandemic Response," 7.

36 Ibid., 8.

37 Annex I International Health Regulation 2005, 6g

38 Davies, Kamradt-Scott, and Rushton, Disease Diplomacy: International Norms and Global Health Security, 93; Gostin, "Influenza A (H1N1) and Pandemic Preparedness Under the Rule of International Law," 2376.

39 Trygve Ottersen, Steven J Hoffman, and Gaëlle Groux, "Ebola Again Shows the International Health Regulations Are Broken: What Can Be Done Differently to Prepare for the Next Epidemic?," American Journal of Law and Medicine 42 (2016): 364.

40 Ibid.

41 Ibid. 
pertemuan tersebut, peristiwa penyebaran yang sedang terjadi telah memenuhi kriteria PHEIC dan mendesak seluruh negara pihak untuk "meningkatkan intensitas pengintaian terhadap penyebaran influenza-like illness dan pneumonia yang tidak biasa." ${ }^{42}$ Dua hari selanjutnya setelah memperoleh informasi epidemiologi lebih jauh, Komite Darurat merekomendasikan level kesiagaan pandemi ditingkatkan dari Fase 3 (limited human-to-human transmission) menjadi Fase 4 (community level outbreak) dan terus meningkat hingga Fase 5 (sustained community transmission). ${ }^{43}$ Puncaknya pada 2010, sebanyak 214 negara melaporkan kasus terkonfirmasi H1N1 dengan total perkiraan kasus berkisar antara puluhan hingga dua ratus juta kasus dan angka kematian mencapai 18.500 kasus. ${ }^{44}$ Pandemi H1N1 akhirnya dinyatakan selesai pada 10 Agustus 2010, setelah Direktur Jenderal WHO menyatakan bahwa dunia telah memasuki periode pasca pandemi.

Empat tahun pasca berakhirnya pandemi H1N1, publik internasional kembali dihadapkan pada Ebola Crisis, yang hingga saat ini, merupakan penyebaran virus ebola terbesar dan paling kompleks dalam sejarah. ${ }^{45}$ Penyebaran penyakit ini bermula dari seorang anak yang tinggal di dekat perbatasan Guinea dengan
Liberia dan Sierra Leone pada akhir 2013; petugas kesehatan Guinea yang tidak familiar dengan ebola menyebabkan kasus tersebut tidak terdeteksi hingga Maret $2014 .{ }^{46}$ Sementara itu, para ilmuwan di Sierra Leone memperkirakan ebola telah menyebar di wilayahnya, yang kemudian dikonfirmasi berhubungan dengan praktik penguburan yang tidak aman di Guinea. Informasi ini, bagaimanapun tidak terdeteksi oleh sistem pengintaian Sierra Leone hingga akhir Mei. Dengan penyebaran pada lebih dari enam puluh lokasi di Guenia, Liberia, dan Sierra Leone pada akhir Juni. ${ }^{47}$ Dengan situasi tersebut, Médecins Sans Frontères (MSF) satusatunya organisasi humaniter internasional yang merawat pasien ebola, mengeluarkan peringatan bahwa ebola sudah "di luar kendali" dan membutuhkan "pengerahan sumber daya secara masif" untuk menahan laju penyebaran. ${ }^{48}$ Pada praktiknya, Ebola Virus Disease (EVD) dapat dikendalikan secara efisien melalui sistem kesehatan publik yang kuat dan kanal komunikasi yang terbuka. Negara pasca konflik seperti Guinea, Liberia, dan Sierra Leone, bagaimanapun, masih harus menghadapi sistem kesehatan publik yang lemah, rendahnya literasi kesehatan, dan sumber daya manusia serta infrastuktur yang tidak memadai adalah faktor

42 World Health Organization, "WHO Ad Hoc Scientific Teleconference on the Current Influenza A(H1N1) Situation," WHO, accessed May 20, 2020, April 29, 2009. www.who.int/csr/resources/publications/swineflu/TC Report2009_05_04. pdf.

43 Davies, Kamradt-Scott, and Rushton, Disease Diplomacy: International Norms and Global Health Security, 96.

44 Ottersen, Hoffman, and Groux, "Ebola Again Shows the International Health Regulations Are Broken: What Can Be Done Differently to Prepare for the Next Epidemic?," 365.

45 Tsung-ling Lee, "Making International Health Regulations Work : Lessons from the Ebola Outbreak, "Vanderbilt Journal of Transnational Law 49, no. 31 (2015): 941.

46 Rebecca Davis, "Ebola Epidemic 2014: Timeline," Guardian, last modified 2014, accessed May 20, 2020, http://www. theguardian.com/world/2014/oct/15/ebola-epidemic-2014-timeline.

47 Lee, "Making International Health Regulations Work : Lessons from the Ebola Outbreak," 942.

48 Ottersen, Hoffman, and Groux, "Ebola Again Shows the International Health Regulations Are Broken: What Can Be Done Differently to Prepare for the Next Epidemic?," 366; Lee, "Making International Health Regulations Work: Lessons from the Ebola Outbreak," 945. 
yang semakin memperparah laju penyebaran ebola di wilayah tersebut. ${ }^{49}$ Setelah proses panjang, ebola resmi dinyatakan sebagai PHEIC pada Agustus 2014, menelan lebih dari 900 korban jiwa. Kasus-kasus ebola juga selanjutnya ditemukan di Italia, Mali, Senegal, Spanyol, Britania Raya, dan Amerika Serikat, dengan total kematian mencapai 11,300 korban jiwa.

\section{b. Lesson Learned: Tantangan IHR dalam Penanganan Pandemi}

Sejak mengalami 'uji coba' pada penanganan pandemi terdahulu, artikel ini selanjutnya akan mengelaborasi tantangan yang muncul dari operasionalisasi IHR 2005. Pertama, dari sisi deklarasi status PHEIC. Sejak berlakunya IHR 2005, terhitung enam kasus peristiwa penyebaran penyakit yang dideklarasikan sebagai PHEIC, kecepatan dan ketepatan deklarasi PHEIC. Pada pandemi H1N1, WHO mendeklarasikan status PHEIC dalam jangka waktu satu bulan sejak deteksi penyebaran pertama di bulan Maret 2009, menjadikan deklarasi PHEIC H1N1 sebagai respons tercepat WHO hingga saat ini. ${ }^{50}$ Respons cepat ini, bagaimanapun, dipandang sebagai langkah yang terbilang prematur oleh para kritikus. WHO disinyalir telah "menimbulkan ketakutan publik", mengingat virus H1N1 bukan merupakan penyakit mematikan, selain kerancuan definisi dari "fase pandemi influenza" yang tidak terdapat pada kerangka kerja IHR $2005 .^{51}$ Sebaliknya, pendeklarasian PHEIC pada kasus Ebola 2014 memakan waktu hingga empat bulan, dengan jumlah korban yang sudah mencapai angka 11.300 jiwa. ${ }^{52}$ Sebagaimana dinyatakan oleh WHO Ebola Interim Assessment

Tabel 2 Deklarasi Status PHEIC oleh WHO

\begin{tabular}{|c|c|c|}
\hline Peristiwa & Tanggal Deklarasi PHEIC & Status \\
\hline H1N1 Pandemi Influenza & 24 April 2009 & Berakhir per 10 Agustus 2010 \\
\hline Wild Poliovirus & 5 Mei 2014 & Aktif \\
\hline 2014-2016 Ebola Afrika Barat & 8 Agustus 2014 2016 \\
\hline 2016 Zika & 1 Februari 2016 & Berakhir per 29 Maret 20r 20 November 2016 \\
\hline $\begin{array}{c}\text { 2018-2020 Ebola Republik } \\
\text { Demokratis Kongo }\end{array}$ & 17 Juli 2019 \\
\hline Coronavirus 2019 & 30 Januari 2020 & Aktif \\
\hline
\end{tabular}

Sumber: von Bogdandy dan Villareal, 2020

Panel, keterlambatan deklarasi PHEIC pada

Pendeklarasian status PHEIC terhadap suatu peristiwa penyebaran penyakit kerap menjadi sorotan para ahli, pertama, dalam hal peristiwa Ebola "berpengaruh signifikan dan tidak dapat dibenarkan." 53 Adapun alasan dari keterlambatan tersebut yakni budaya

49 Lee, "Making International Health Regulations Work : Lessons from the Ebola Outbreak," 944.

50 Steven J. Hoffman and Sarah L. Silverberg, "Delays in Global Disease Outbreak Responses: Lessons from H1N1, Ebola, and Zika," American Journal of Public Health 108, no. 3 (2018): 330.

51 Gostin, Debartolo, and Friedman, "The International Health Regulations 10 Years on : The Governing Framework for Global Health Security," 273.

52 Lawrence O Gostin, "The Future of the World Health Organization: Lessons Learned From Ebola," The Milbank Quarterly 93, no. 3 (2015): 476; Gostin, Debartolo, and Friedman, "The International Health Regulations 10 Years on : The Governing Framework for Global Health Security," 274.

53 Komite yang terdiri dari para ahli independen ini dibentuk khusus untuk mengkaji respons WHO terhadap penyebaran EVD; Ottersen, Hoffman, and Groux, "Ebola Again Shows the International Health Regulations Are Broken: What Can Be Done Differently to Prepare for the Next Epidemic?," 375. 
organisasi WHO, masalah dalam arus informasi, struktur pengambilan keputusan regional WHO, dan kesulitan bernegosiasi dengan negara terdampak. Lebih jauh, sejumlah peringatan dari MSF dan institusi lainnya tidak sampai pada perhatian jajaran pimpinan WHO; diduga, peringatan tersebut tidak dianggap sebagai hal yang signifikan. ${ }^{54}$ Isu inkonsistensi dalam pendeklarasian PHEIC kemudian mengundang pertanyaan mengenai transparansi dalam proses pengambilan keputusan dalam WHO yang ditengarai bersifat politis ketimbang perdebatan teknis. Secara khusus, isu inklusivitas dalam proses deliberasi menjadi harga yang harus dibayar untuk mempercepat proses pengambilan keputusan..$^{55}$

Isu kedua dalam pendeklarasian PHEIC ialah keberadaan kerangka kerja WHO lainnya yakni Pandemic Influenza Preparedness dan Emergency Health Response yang menimbulkan kerancuan dalam penentuan respons atas suatu peristiwa yang berpotensi memicu PHEIC. Dalam kasus H1N1, kebingungan dipicu oleh keberadaan Pandemic Influenza Preparedness menjadi dasar bagi WHO dalam mendeklarasikan PHEIC melalui peningkatan gradual fase-fase dalam pedoman tersebut. ${ }^{56}$ Padahal dari sisi legalitas, IHR 2005 tidak memuat ketentuan yang menyebutkan, apalagi mengizinkan hal apapun terkait dengan sistem kewaspadaan pandemi influenza tersebut. Hal serupa terulang kembali dalam penanganan Ebola 2014, yakni penggunaan Emergency Response Framework yang ditujukan untuk menilai severity dari suatu penyebaran penyakit dalam rangka penentuan status PHEIC. ${ }^{57}$

Tantangan selanjutnya yang dihadapi IHR ialah terkait kapasitas inti nasional (national core capacities) yang dimiliki oleh negara anggota. Mendekati tenggat waktu dalam pemenuhan national capacities, WHO merilis survei kesiapan implementasi ketentuan ini: hanya 66\% dari 194 negara anggota merespons survei tersebut, dengan $10 \%$ negara yang berhasil mengimplementasikan kapasitas minimum secara penuh. ${ }^{58}$ Terbukti, meskipun telah dilakukan perpanjangan tenggat waktu selama empat tahun hingga 2016, terhitung hanya 64 dari 81 negara pihak yang dinyatakan memenuhi ketentuan national core capacities IHR. $^{59}$ Pasca H1N1 dan Ebola, baik negara berkembang maupun negara terbelakang mengalami ketertinggalan dalam memenuhi mandat kapasitas minimum yang disebabkan oleh ketiadaan infrastruktur kesehatan. ${ }^{60}$ Kondisi ini dipersulit dengan tidak adanya pembiayaan inisiatif kesehatan global yang cukup dan terkoordinasi dengan baik untuk memberikan pendampingan. ${ }^{61}$ Lebih lanjut, diperlukan mekanisme tertentu yang dapat memfasilitasi negara-negara maju untuk memberikan pendampingan peningkatan kapasitas melalui

54 Ibid.

55 Bogdandy and Villarreal, International Law on Pandemic Response: A First Stocktacking in Light of the Coronavirus Crisis, 14.

56 Davies, Kamradt-Scott, and Rushton, Disease Diplomacy: International Norms and Global Health Security, 96.

57 Gostin, Debartolo, and Friedman, "The International Health Regulations 10 Years on : The Governing Framework for Global Health Security," 2225

58 Ottersen, Hoffman, and Groux, "Ebola Again Shows the International Health Regulations Are Broken: What Can Be Done Differently to Prepare for the Next Epidemic?," 367.

59 Gostin, "The Future of the World Health Organization: Lessons Learned From Ebola," 2223.

60 Gostin, "Influenza A (H1N1) and Pandemic Preparedness Under the Rule of International Law," 2377.

61 Kumanan Wilson, John S. Brownstein, and David P. Fidler, "Strengthening the International Health Regulations: Lessons from the H1N1 Pandemic," Health Policy and Planning 25, no. 6 (2010): 56. 
konferensi, perencanaan yang melibatkan berbagai pemangku kebijakan, maupun pembentukan international funding. ${ }^{62}$ Isu national core capacities juga dipandang sebagai potensi distorsi terhadap prioritas kesehatan nasional. PHEIC merupakan masalah utama bagi negara maju dengan sistem kesehatan nasional yang sudah mapan, bagaimanapun, negara berkembang akan kesulitan untuk mengalokasikan sumber daya lebih untuk mengantisipasi PHEIC yang sudah kewalahan untuk membangun sistem kesehatan nasional yang layak. ${ }^{63}$

Keempat, IHR 2005 dalam penanganan pandemi sangat berpotensi untuk bersinggungan dengan isu lain seperti migrasi, perdagangan internasional, hingga hak asasi manusia. Meskipun WHO telah menyatakan bahwa pembatasan perjalanan internasional tidak memilikidampaksignifikan terhadap penyebaran H1N1, banyak negara memberlakukan travel ban dari dan ke Meksiko. ${ }^{64}$ Lebih jauh, ketakutan akan penyebaran H1N1 melalui daging babi menjadi latar belakang pelarangan impor daging babi dari Meksiko, Amerika Serikat, dan Kanada di setidaknya dua puluh negara. Kondisi tersebut berakhir pada klaim pelanggaran hukum perdagangan internasional yang diajukan oleh Meksiko ke World Trade Organization (WTO). ${ }^{65}$ Rekomendasi WHO untuk melakukan social distancing dan upaya karantina akan berkaitan erat dengan pembatasan hak sipil warga negara yang, meskipun telah tercantum pada Pasal 2 dan
32 IHR 2005, masih belum memuat penjelasan spesifik tentang teknis implementasi di masa pandemi. ${ }^{66}$ Terakhir, karakter IHR 2005 sebagai kerangka kerja hukum internasional tentu menghadapi tantangan dalam hal penegakan (enforcement). Hingga IHR 2005, tidak ada ketentuan mengenai penalti bagi kegagalan negara pihak untuk melaporkan peristiwa berpotensi PHEIC maupun kegagalan memenuhi national core capacities; dalam hal ini, WHO tidak memiliki kekuatan formil untuk memaksakan para negara pihak agar mematuhi (to comply) IHR 2005 sepenuhnya. Ketiadaan mekanisme ajudikasi dipahami sebagai bentuk kompromi WHO atas isu sovereignty dari masing-masing negara pihak. ${ }^{67}$ Ketiadaan mekanisme formal untuk merespons tindakan-tindakan yang tidak berbasis bukti (non-evidence based) seperti pembatasan perjalanan dan perdagangan juga menjadi pekerjaan rumah bagi kerangka kerja IHR 2005.

\section{IHR dan Covid-19: Perkembangan Penanganan Pandemi Hingga Saat Ini}

Pada bagian ini, pembahasan akan difokuskan pada penerapan IHR 2005 dalam penanganan pandemi Covid-19 dengan analisis terhadap aspek-aspek IHR, yakni deklarasi PHEIC melalui notifikasi dan informasi, kapasitas minimum negara pihak, serta permissible health measures yang telah dilaksanakan oleh negara pihak.

Linimasa penyebaran Covid-19 dimulai pada akhir Desember 2016 dengan penemuan kasus

62 Ottersen, Hoffman, and Groux, "Ebola Again Shows the International Health Regulations Are Broken: What Can Be Done Differently to Prepare for the Next Epidemic?," 370.

63 Wilson, Brownstein, and Fidler, "Strengthening the International Health Regulations: Lessons from the H1N1 Pandemic."

64 Gostin, "Influenza A (H1N1) and Pandemic Preparedness Under the Rule of International Law," 2378.

65 Ibid.

66 Bogdandy and Villarreal, International Law on Pandemic Response: A First Stocktacking in Light of the Coronavirus Crisis, 17.

67 Katz and Fischer, "The Revised International Health Regulations : A Framework for Global Pandemic Response," 12. 
Gambar 1 Linimasa Penyebaran Covid-19 di Tiongkok

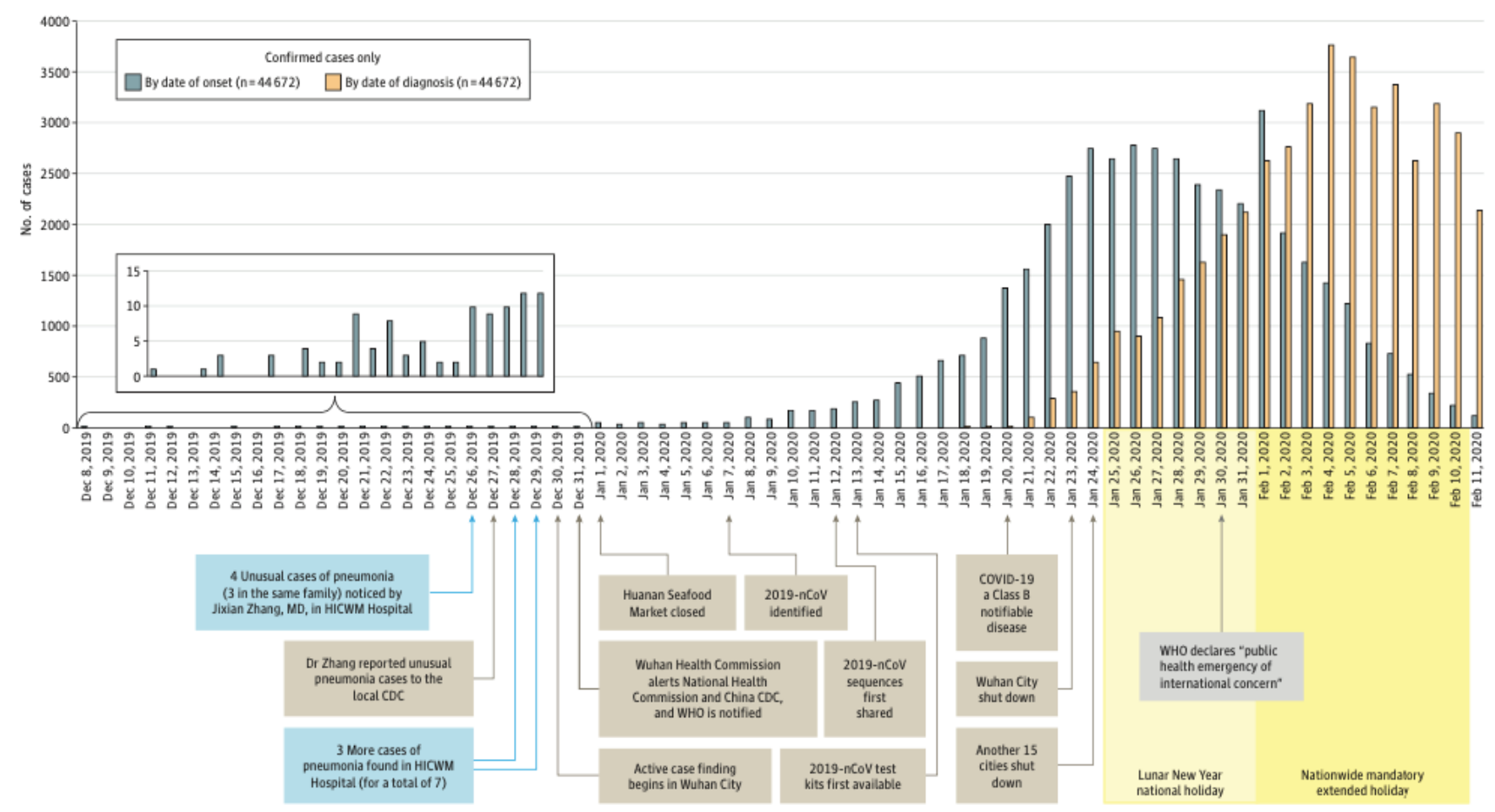

Sumber: Wu dan McGoogan 2020

misterius pneumonia like-illnesses. Lima hari sejak kemunculan pertama, otoritas kesehatan Wuhan selanjutnya melaporkan kondisi ini ke Tiongkok CDC yang pada akhirnya memberikan notifikasi ke WHO. ${ }^{68}$ Sebagaimana Pasal 12 IHR 2005, pendeklarasian status PHEIC salah satunya perlu mempertimbangkan saran dari Komite Darurat, yang, dalam hal ini, menjadi preseden baru dalam sejarah WHO. Pertemuan Komite Darurat pertama pada 22 Januari 2020 gagal menghasilkan kesimpulan terkait kriteria PHEIC dalam kasus Covid-19; Komite Darurat menggelar voting yang berakhir seri, hal yang baru pertama kali terjadi. ${ }^{69}$ Selanjutnya pada pertemuan kedua, Komite Darurat masih belum mencapai kesepakatan untuk mendeklarasikan status PHEIC yang dilatarbelakangi oleh "...the lack of necessary data and the (then) scale of global impact", mengingat hanya ditemukan empat kasus penyebaran di luar Tiongkok. ${ }^{70}$ Terjebak dalam definisi, Komite Darurat menyatakan bahwa peristiwa Covid-19 belum memenuhi kriteria "international spread" yang tercantum dalam Pasal 1 IHR 2005. Padahal apabila ditelusuri lebih jauh, definisi PHEIC adalah "extraordinary event which is determined to constitute a public health risk to other States through the international spread of disease and to potentially require a coordinated international response" ${ }^{71}$ Definisi

68 Wu and McGoogan, "Characteristics of and Important Lessons From the Coronavirus Disease 2019 (COVID-19) Outbreak in China."

69 Mark-Eccleston Turner, "COVID-19 Symposium: The Declaration of a Public Health Emergency of International Concern in International Law," Opinio Juris, last modified 2020, accessed June 2, 1BC, http://opiniojuris.org/2020/03/31/covid19-symposium-the-declaration-of-a-public-health-emergency-of-international-concern-in-international-law/.

70 Ibid.

71 Pasal 12 ayat (1) IHR 2005 
ini secara gamblang menyatakan bahwa PHEIC memiliki risiko penyebaran internasional di dalamnya; karakteristik yang jelas-jelas dimiliki oleh Covid-19. Hingga akhirnya pada pertemuan ketiga, Komite Darurat mendeklarasikan peristiwa Covid-19 sebagai PHEIC, dengan total 7.818 kasus terkonfirmasi di seluruh dunia yang meliputi sembilan belas negara anggota di lima regional WHO. ${ }^{72}$ Lagi-lagi, kritikus menyorot keterlambatan yang tidak berdasar (undue delay) dalam pendeklarasian PHEIC dan menimbulkan pertanyaan mengenai pertanggungjawaban organisasi internasional, hingga mempertanyakan kegunaan dari proses penentuan PHEIC sebagai fungsi dari hukum internasional. ${ }^{73}$

Aspek kapasitas inti negara menjadi pekerjaan rumah utama dalam penanganan pandemi terdahulu, sebuah tugas yang masih belum terselesaikan pada pandemi Covid-19. Berdasarkan sebuah studi yang menganalisis laporan tahunan negara pihak (State Party Annual Reporting/SPAR) IHR 2005, ditemukan bahwa dari total 182 negara pihak, kapasitas pencegahan, deteksi, dan respons terhadap penyebaran penyakit sangatlah bervariasi. ${ }^{74}$ Lebih lanjut, keberadaan pelayanan kesehatan utama di level komunitas dipandang sangat penting bagi kemampuan suatu negara untuk meminimalkan fase awal potensi kedaruratan kesehatan. ${ }^{75}$ Ketika terjadi penyebaran penyakit, sistem kesehatan nasional harus cukup kuat untuk memastikan pelayanan kesehatan utama -sesuatu yang sulit diakses oleh warga negara dengan sumber daya minim. Kesiapan operasional akan situasi darurat memungkinkan negara untuk memberikan respons yang cepat, mangkus, dan sangkil dalam kondisi pandemi. Bagaimanapun, kondisi tersebut merupakan suatu proses "establishing, strengthening, and maintaining" infrastuktur multisektoral yang dapat diterapkan pada seluruh tingkatan dan fokus pada risiko prioritas tertinggi. ${ }^{76}$ Studi ini juga menunjukkan bahwa hanya setengah dari 182 negara yang memiliki sumber daya cukup untuk kondisi darurat; negara dengan status ekonomi negara-negara berpenghasilan tinggi atau berpenghasilan menengah. ${ }^{77}$

Terakhir, negara-negara di dunia melakukan tindakan permissible health measures yang bervariasi dalam rangka memperlambat laju penyebaran Covid-19. Mulai dari karantina lokal seperti yang dilakukan di Kota Wuhan, ${ }^{78}$ hingga tes masif dan penelusuran kontak seperti yang dilakukan oleh Korea Selatan dan Singapura. ${ }^{79}$ Apabila merujuk kepada rekomendasi WHO, public health measures yang disarankan dalam konteks Covid-19 salah satunya ialah melalui karantina

"Public health measures to achieve these

Ducharme, "World Health Organization Declares COVID-19 a 'Pandemic.' Here's What That Means."

73 Turner, "COVID-19 Symposium: The Declaration of a Public Health Emergency of International Concern in International Law."

74 Nirmal Kandel et al., "Health Security Capacities in the Context of COVID-19 Outbreak : An Analysis of International Health Regulations Annual Report Data from 182 Countries," The Lancet 395, no. 10229 (2020): 1047-1053, http:// dx.doi.org/10.1016/s0140-6736(20)30553-5.

75 Ibid.

76 Ibid.

77 Ibid.

78 Wu and McGoogan, "Characteristics of and Important Lessons From the Coronavirus Disease 2019 (COVID-19) Outbreak in China," 1241.

79 Heleno Rodrigues Corrêa Filho and Ana Maria Segall-Corrêa, "Lockdown or Participatory Health Surveillance? Lessons from the Covid-19," Saúde em Debate 44, no. 124 (2020): 13. 
goals may include quarantine, which involves the restriction of movement, or separation from the rest of the population, of healthy persons who may have been exposed to the virus, with the objective of monitoring their symptoms and ensuring early detection of cases." ${ }^{\prime \prime 0}$

Dalam hal ini, karantina tidak ditujukan terhadap orang-orang yang telah dinyatakan positif terpapar Covid-19, melainkan terhadap orang-orang yang berpotensi telah melakukan kontak dengan virus maupun pembawa virus Sars-CoV2. Karantina dilakukan untuk mengawasi gejala yang dialami dan memastikan deteksi dini terhadap kasus baru. ${ }^{81}$ Secara normatif, opsi ini telah tercantum dalam IHR 2005 yakni Pasal 30 (Travelers under public health observation), Pasal 31 (Health measures relating to entry of travelers), dan Pasal 32 (Treatment of travelers). Lebih lanjut, WHO menekankan bahwa terdapat beberapa prasyarat pemberlakuan karantina, mulai dari pedoman yang jelas, transparan, konsisten, dan up-to-date terkait tindakan karantina hingga jaminan ketersediaan pelayanan kesehatan, dukungan finansial, sosial, dan psikososial, serta kebutuhan dasar seperti pangan. ${ }^{82}$

Seiring perkembangan kasus penyebaran Covid-19, karantina tidak lagi menjadi media pencegahan yang signifikan, mengingat penularan sudah tidak lagi terjadi melalui kasus impor dari orang-orang yang bepergian, melainkan sudah pada tahapan penularan lokal. Pada level tertentu, negara-negara mulai mengambil langkah drastis seperti menutup sekolah dan memberlakukan pembelajaran jarak jauh, melarang kegiatan berkumpul dalam jumlah besar, pembatasan perjalanan, hingga memberlakukan jam malam (curfew). ${ }^{83}$ Komunitas internasional di berbagai belahan dunia juga turut andil mempromosikan gerakan pembatasan sosial (social/physical distancing) dengan tetap tinggal di rumah dan membatasi kegiatan bepergian. Kondisi demikian semakin memperjelas andil 'kapasitas inti negara' yang ditentukan oleh IHR 2005 dalam penanganan pandemi sekaligus mempertegas gap sumber daya yang dimiliki oleh negara pihak. Di satu sisi, permissible health measures dapat menjadi pelengkap bagi negara-negara maju dengan sistem kesehatan yang sudah mapan. Disisi lain, bagi negara dengan sistem kesehatan yang masih lemah dengan ketersediaan pelayanan kesehatan dasar terbatas, permissible health measures yang dilakukan akan sangat mungkin menimbulkan masalah-masalah baru, khususnya problematika sosial-ekonomi masyarakat. ${ }^{84}$

Patut dipahami bahwa upaya pencegahan penyebaran Covid-19 baik melalui karantina maupun permissible health measures lainnya, bagaimanapun, tidak dapat dilihat dari sisi kesehatan semata. Kebijakan menutup sekolah dan menggeser kegiatan belajar dari metode klasikal tatap muka menjadi pembelajaran jarak

80 WHO, "Considerations for Quarantine of Individuals in the Context of Containment for Coronavirus Disease (COVID-19)," Interim Guidance (Geneva: WHO, 2020), 1.

81 WHO, "Considerations for Quarantine of Individuals in the Context of Containment for Coronavirus Disease (COVID-19)."

82 Ibid.

83 Lawrence O. Gostin and Lindsay F. Wiley, "Governmental Public Health Powers during the COVID-19 Pandemic: Stayat-Home Orders, Business Closures, and Travel Restrictions," JAMA - Journal of the American Medical Association (2020): 7-8.

84 James A. Smith and Jenni Judd, "COVID-19: Vulnerability and the Power of Privilege in a Pandemic," Health Promotion Journal of Australia 31, no. 2 (2020): 158-160. 
jauh misalnya, akan memperjelas kesenjangan sosial akan akses terhadap media pembelajaran perangkat ponsel pintar dan jaringan internet yang belum tentu dimiliki oleh seluruh peserta didik. Pembatasan perjalanan internasional akan berdampak secara finansial pada pekerja migran yang merupakan tulang punggung ekonomi keluarga. ${ }^{85}$ Seruan untuk tetap di rumah menjadi hambatan utama bagi pekerja sektor informal yang mengandalkan penghasilan harian akan berimplikasi pada kehilangan pemasukan sementara dan peningkatan angka kemiskinan. ${ }^{86}$

Pandemi Covid-19 secara tidak langsung menegaskan bahwa penanganan krisis kesehatan global akan bersinggungan dengan isu hukum serta hak asasi manusia, sehingga diperlukan pendekatan yang lebih komprehensif. Mengutip pernyataan Direktur Jenderal WHO, "all countries must strike a fine balance between protecting health, preventing economic and social disruption, and respecting human rights, "87 sesuatu yang tidak mungkin dapat dicapai apabila hanya mengandalkan kerangka kerja IHR semata.

\section{Penutup}

Artikel ini mengidentifikasi bahwa sesungguhnya hukum internasional telah memiliki mekanisme dalam penanganan pandemi global melalui organisasi internasional WHO. Sebagai organisasi internasional di bidang kesehatan, WHO memiliki mandat dan kewenangan besar dalam penanganan pandemi, terutama pasca berlakunya kerangka kerja International Health Regulation (IHR) 2005. Operasionalisasi kerangka kerja IHR pada penanganan pandemi terdahulu seperti H1N1 dan Ebola Virus Disease pada derajat tertentu berhasil mempertegas celah-celah yang dimiliki oleh IHR 2005, baik dari sisi teknis kesehatan maupun isu hukum seperti compliance negaranegara pihak terhadap rekomendasi WHO sebagai produk hukum yang lahir dari mekanisme kerangka kerja IHR 2005. Pandemi Covid-19 lagi-lagi menimbulkan pertanyaan mengenai transparansi proses pengambilan keputusan dalam organisasi WHO, serta menyorot isu compliance negara pihak terhadap keputusan organisasi yang, pada gilirannya, berimplikasi pada keberhasilan suatu negara dalam penanganan pandemi. Terlebih, upaya IHR 2005 dalam mengakomodasi isu-isu sosial ekonomi dan hak asasi manusia, pada praktiknya, masih luput dari perhatian para negara pihak ketika dihadapkan pada situasi kedaruratan kesehatan global. Hal ini akhirnya mengantarkan kita pada gagasan bahwa, IHR 2005 sebagai kerangka kerja hukum internasional, tidak bisa dianggap sebagai instrumen 'one size fits all' yang mampu menyelesaikan seluruh permasalahan penanganan krisis kesehatan global.

85 Clare Wenham, Julia Smith, and Rosemary Morgan, "COVID-19: The Gendered Impacts of the Outbreak," The Lancet 395, no. 10227 (2020): 847, http://dx.doi.org/10.1016/S0140-6736(20)30526-2.

86 International Labour Organization, "COVID-19 Crisis and the Informal Economy: Immediate Responses and Policy Challenges" (Geneva: International Labour Organization, 2020).

87 Smith and Judd, "COVID-19: Vulnerability and the Power of Privilege in a Pandemic." 


\section{Daftar Pustaka}

\section{A. Buku}

Banakar, Reza. Normativity in Legal Sociology: Methodological Reflections on Law and Regulation in Late Modernity. London: Springer, 2015.

Davies, Sara E., Adam Kamradt-Scott, and Simon Rushton. Disease Diplomacy: International Norms and Global Health Security. Baltimore: Johns Hopkins University Press, 2015.

\section{B. Artikel Jurnal/Kertas Kerja}

Bogdandy, Armin Von, and Pedro A Villarreal. International Law on Pandemic Response: A First Stocktacking in Light of the Coronavirus Crisis. MPIL Research Paper Series. Heidelberg, 2020.

Corrêa Filho, Heleno Rodrigues, and Ana Maria Segall-Corrêa. "Lockdown or Participatory Health Surveillance? Lessons from the Covid-19." Saúde em Debate 44, no. 124 (2020).

Cryer, Robert, Tamara Hervey, Bal Sokhi-Bulley, and Alexandra Bohm. Research Methodologies in EU and International Law. Portland: Hart Publishing, 2011.

European Centre for Disease Prevention and Control. "Event Background COVID-19." COVID-19. Gostin, Lawrence O., and Lindsay F. Wiley. "Governmental Public Health Powers during the COVID-19 Pandemic: Stay-at-Home Orders, Business Closures, and Travel Restrictions." JAMA - Journal of the American Medical Association (2020).

Gostin, Lawrence O. "Influenza A (H1N1) and Pandemic Preparedness Under the Rule of International Law." JAMA Network, 2009.

- - - "The Future of the World Health Organization: Lessons Learned From Ebola." The Milbank Quarterly 93, no. 3 (2015).

Gostin, Lawrence O, Mary C Debartolo, and Eric A Friedman. "The International Health Regulations 10 Years on: The Governing Framework for Global Health Security." The Lancet 386, no. 10009 (2015).

Hakim, Muhammad Helmy. "Pergeseran Orientasi Penelitian Hukum: Dari Doktrinal Ke Sosio Legal." SYARIAH Jurnal Hukum dan Pemikiran 16, no. 2 (2016).

Hoffman, Steven J., and Sarah L. Silverberg. "Delays in Global Disease Outbreak Responses: Lessons from H1N1, Ebola, and Zika." American Journal of Public Health 108, no. 3 (2018). International Labour Organization. "COVID-19 Crisis and the Informal Economy: Immediate Responses and Policy Challenges." Geneva: International Labour Organization, 2020.

Kandel, Nirmal, Stella Chungong, Abbas Omaar, and Jun Xing. "Health Security Capacities

in the Context of COVID-19 Outbreak: An Analysis of International Health Regulations Annual Report Data from 182 Countries." The Lancet 395, no. 10229 (2020).

Katz, Rebecca, and Julie Fischer. "The Revised International Health Regulations : A Framework for Global Pandemic Response." Global Health Governance 3, no. 2 (2010).

Kennedy, David W. "The Move to Institutions." Cardozo Law Review 8 (1987). Kharel, Amrit. "Doctrinal Legal Research." SSRN Electronic Journal 16 (2018).

Lee, Tsung-ling. "Making International Health Regulations Work: Lessons from the Ebola Outbreak." Vanderbilt Journal of Transnational Law 49, no. 31 (2015).

Lerer, L., and R. Matzopoulos. "'The Worst of Both Worlds': The Management Reform of the World Health Organization." International Journal of Health Services 31, no. 2 (2001).

Mccarthy, Michael. "A Brief History of the World Health Organization D." The Lancet 360 
(2002).

Ottersen, Trygve, Steven J Hoffman, and Gaëlle Groux. "Ebola Again Shows the International Health Regulations Are Broken: What Can Be Done Differently to Prepare for the Next Epidemic?" American Journal of Law and Medicine 42 (2016).

Smith, James A., and Jenni Judd. "COVID-19: Vulnerability and the Power of Privilege in a Pandemic." Health Promotion Journal of Australia 31, no. 2 (2020).

Spiteri, Gianfranco, James Fielding, Michaela Diercke, Christine Campese, Enouf Vincent, Alexandre Gaymard, Antonino Bella, et al. "First Cases of Coronavirus Disease 2019 (COVID-19) in the WHO European Region, 24 January to 21 February 2020." Eurosurveillance 25, no. 9 (2020).

Wenham, Clare, Julia Smith, and Rosemary Morgan. "COVID-19: The Gendered Impacts of the Outbreak." The Lancet 395, no. 10227 (2020).

WHO. "Considerations for Quarantine of Individuals in the Context of Containment for Coronavirus Disease (COVID-19)." Interim Guidance. Geneva: WHO, 2020.

- - . "WHO Ad Hoc Scientific Teleconference on the Current Influenza A(H1N1) Situation." WHO. Accessed May 20, 2020. April 29, 2009. www.who.int/csr/resources/publications/ swineflu/TC Report2009_05_04.pdf.

Wilson, Kumanan, John S. Brownstein, and David P. Fidler. "Strengthening the International Health Regulations: Lessons from the H1N1 Pandemic." Health Policy and Planning 25, no. 6 (2010).

Wu, Zunyou, and Jennifer M. McGoogan. "Characteristics of and Important Lessons From the Coronavirus Disease 2019 (COVID-19) Outbreak in China." JAMA Network, 2020.

\section{Artikel Internet}

Davis, Rebecca. "Ebola Epidemic 2014: Timeline." Guardian. Last modified 2014. Accessed May 20, 2020. http://www.theguardian.com/world/2014/oct/15/ebola-epidemic-2014timeline.

Ducharme, Jamie. "World Health Organization Declares COVID-19 a 'Pandemic.' Here's What That Means." TIME. Last modified 2020. Accessed May 2, 2020. https://time. com/5791661/who-coronavirus-pandemic-declaration/.

Turner, Mark-Eccleston. "COVID-19 Symposium: The Declaration of a Public Health Emergency of International Concern in International Law." Opinio Juris. Last modified 2020. Accessed June 2, 1BC. http://opiniojuris.org/2020/03/31/covid-19-symposium-the-declaration-ofa-public-health-emergency-of-international-concern-in-international-law/.

World Health Organization. Novel Coronavirus (2019-NCoV) Situation Report - 1, 20 January 2020. Geneva, 2020. https://www.who.int/docs/default-source/coronaviruse/situationreports/20200121-sitrep-1-2019-ncov.pdf?sfvrsn=20a99c10_4.

- - - "WHO Director-General's Opening Remarks at the Media Briefing on COVID-19 - 3 March 2020." Last modified 2020. Accessed May 2, 2020. https://www.who.int/dg/ speeches/detail/who-director-general-s-opening-remarks-at-the-media-briefing-oncovid-19---3-march-2020.

\section{Peraturan Perundang-undangan}

United Nations. "Constitution of the World Health Organization." United Nations Treaty Collection. Accessed May 3, 2020. https://treaties.un.org/Pages/ShowMTDSGDetails.asp 
$x$ ?src=UNTSONLINE\&tabid=2\&mtdsg_no=IX-1\&chapter=9\&lang=en.

World Health Organization. International Health Regulation. 2nd ed. Geneva: WHO, 2005. World Health Organization (1969). International Health Regulation. 3rd ed. Geneva: WHO, 1983. 


\section{BIODATA PENULIS}

Sabrina Nadilla, S.H., staff pada Pusat Litbang HAM, Badan Penelitian dan Pengembangan Hukum dan HAM, Kementerian Hukum dan HAM Republik Indonesia sejak Republik Indonesia sejak 2017. Penulis memperoleh gelar Sarjana gelar Sarjana Hukum dengan konsentrasi hukum internasional dari Fakultas Hukum Universitas Gadjah Mada pada 2017. Penulis menekuni area riset teori hukum, institusionalisme hukum, hak asasi manusia, dan studi sosio-legal. Beberapa karya tulis ilmiah yang telah dipublikasika di antaranya "Pelokalan Hak Asasi Manusia Melalui Partisipasi Publik dalam Kebijakan Berbasis Hak Asasi Manusia" dan "Konsolidasi SDM Hukum Nasional melalui Pendekatan Teori Sistem Hukum Luhmann." 